JP3I (Jurnal Pengukuran Psikologi dan Pendidikan Indonesia), 9(2), 2020, 83-98

D01: http://dx.doi.org/I0.15408/jp3i.v9i2.XXXXX

http://journal.uinjkt.ac.id/index.php/jp3i

\title{
Pengembangan Asesmen Higher Order Thinking Skills (HOTS) Berbasis Computer Based Test (CBT) pada Materi Induksi Elektromagnetik
}

\author{
Bayu Pranata ${ }^{1}$, Agus Suyatna, Undang Rosidin \\ Magister Pendidikan Fisika, Fakultas Pendidikan Ilmu Pengetahuan, Universitas Lampung, Indonesia \\ pranata.bayu31@gmail.com ${ }^{1}$
}

\begin{abstract}
The research objective was to produce assessment product for Higher Order Thinking Skills (HOTS) using Computer Based Test (CBT) with four types of HOTS questions (true or false, multiple choices, fill in the blank and matching). It applied the basis of factual, conceptual, procedural and metacognitive-knowledge dimensions with illustrations in the form of discourse, images, graphics, videos, animation and interactive stimulation and feedback after going through the stages of logical validation, empirical validation and respondent questionnaires. Assessment product HOTS using CBT was implemented to Senior High School students in the learning process of physics subject through $R \& D$ research steps proposed by Borg and Gall that aimed to stimulate higher-order thinking skills. This is a development research in which the method was conducted by giving HOTS test questions using CBT to measure students' HOTS profiles and distributing practical questionnaires related to students' perceptions toward assessment products of HOTS using CBT. The data collection technique was carried out using expert validation sheet and respondent questionnaire. Then, the collected data was analyzed in descriptive quantitative. The analysis showed that the logical validity obtained from expert validation on HOTS assessment using CBT was $81 \%$ with a valid category. Empirical validity was obtained from students' HOTS test results using CBT which showed that the four types of questions were able to measure students' HOTS. In addition, students' responses on practical aspects were $86.75 \%$ with a very practical category. The results of the data showed that the development of assessment product of HOTS using CBT in electromagnetic induction material for Physics subject in Senior High School is already valid and practical. Thus, it was concluded that the development of HOTS assessment using CBT has already contained the right stimulus and is able to encourage students to think using HOTS.
\end{abstract}

Keywords: assessment, computer based test (CBT), higher order thinking skills (HOTS), and knowledge dimensions.

\begin{abstract}
Abstrak
Tujuan dari penelitian ini adalah untuk menghasilkan produk asesmen Higher Order Thinking Skills (HOTS) berbasis Computer Based Test (CBT) dengan empat tipe soal HOTS (true or false, multiple choice, fill in the blank dan matching) berbasis dimensi pengetahuan faktual, konseptual, prosedural dan metakognitif dengan ilustrasi berupa wacana, gambar, grafik, video, animasi dan stimulasi interaktif serta pemberian feedback setelah melalui tahap validasi logis, validasi empiris, dan kuesioner responden. Produk asesmen HOTS berbasis CBT diimplementasikan kepada peserta didik SMA dalam pembelajaran fisika dengan langkah-langkah penelitian R\&D menurut Borg and Gall yang bertujuan untuk menstimulus kemampuan berpikir tingkat tinggi. Penelitian ini merupakan penelitian pengembangan dengan metode yang digunakan yaitu dengan memberikan soal tes HOTS berbasis CBT untuk mengukur profil HOTS peserta didik dan membagikan kuesioner kepraktisan yang berkaitan dengan persepsi peserta didik terhadap produk asesmen HOTS berbasis CBT. Teknik pengumpulan data menggunakan lembar validasi ahli dan kuesioner responden, kemudian data yang terkumpul dianalisis secara kuantitatif deskriptif. Analisis menunjukkan bahwa validitas logis yang diperoleh dari validasi ahli pada asesmen HOTS berbasis CBT sebesar 81\% dengan kategori valid, validitas empiris diperoleh dari hasil tes HOTS berbasis
\end{abstract}


CBT peserta didik yang menunjukkan bahwa keempat tipe soal mampu mengukur HOTS peserta didik, sedangkan respons peserta didik pada aspek kepraktisan sebesar 86,75\% dengan kategori sangat praktis. Hasil data menunjukkan produk asesmen HOTS berbasis CBT pada materi Induksi Elektromagnetik untuk Mata Pelajaran Fisika di Sekolah Menengah Atas yang dikembangkan sudah tergolong valid dan praktis sehingga diperoleh kesimpulan bahwa asesmen HOTS berbasis CBT yang dikembangkan sudah mengandung stimulus yang tepat dan mampu mendorong peserta didik untuk berpikir HOTS.

Kata Kunci: asesmen, computer based test (CBT), higher order thinking skills (HOTS), dan dimensi pengetahuan.

\section{Pendahuluan}

Bidang pendidikan merupakan prioritas utama dalam program pemerintahan di Indonesia pada saat ini. Program up to date pemerintah saat ini adalah bahwa pemerintah Indonesia mewacanakan transformasi pendidikan 4.0 untuk menumbuhkan generasi emas yang siap berkompetisi di era revolusi industri 4.0.Unsur teknologi saat ini menjadi hal wajib yang perlu dimasukkan dalam dunia pendidikan karena teknologi tak hanya penting untuk membuka akses literasi secara lebih luas, tapi juga menjadi kunci pemerataan kualitas pendidikan di seluruh daerah.

Saat ini peserta didik diarahkan untuk berpikir tingkat tinggi dalam proses pembelajaran di sekolah. Berpikir tingkat tinggi merupakan keterampilan yang membutuhkan kemampuan seperti menganalisis, mengevaluasi, dan menciptakan. Berdasarkan data yang dirilis oleh Organisation for Economic Cooperation and Development (OECD) disebutkan bahwa berdasarkan hasil survei Programme of International Student Assessment (PISA) pada tahun 2015, peserta didik Indonesia berada pada peringkat 62 dari 70 negara peserta. Dalam survei tersebut soal yang terdapat dalam PISA berupa soal Higher Order Thinking Skills (HOTS). Hal ini menunjukkan bahwa tingkat berpikir peserta didik di Indonesia masih rendah dibandingkan dengan negara lain (Syahputra \& Surya, 2017).

Salah satu bidang ilmu yang menjadi landasan dalam pengembangan penelitian ini yaitu mata pelajaran Fisika. Mata pelajaran ini merupakan jenis mata pelajaran eksakta yang masih dirasa sulit oleh kebanyakan peserta didik khususnya untuk peserta didik setingkat SMA. Penyebab utamanya adalah bersifat abstrak dan banyak rumus matematika. Sedangkan pada hakikatnya Fisika adalah proses cara berpikir yang digunakan dalam memahami gejala alam contohnya pada materi induksi elektromagnetik diharapkan peserta didik dapat memahami gejala alam mengenai induksi elektromagnetik baik dari pergerakan aliran elektron, aliran arus listrik, dan garis-garis medan magnet.

Berdasarkan hasil survei yang dilakukan dengan beberapa guru Fisika Sekolah Menengah Atas (SMA) di Kecamatan Belitang Kabupaten OKU Timur, menunjukkan bahwa sebanyak 80\% guru pernah membuat instrumen tes HOTS, namun hanya sebatas menguji kemampuan menganalisis peserta didik. Sebanyak $40 \%$ hanya sebatas menguji kemampuan mengevaluasi peserta didik. Sedangkan tidak ada guru yang pernah membuat instrumen tes HOTS untuk menguji kemampuan mengkreasi peserta didik. Hal tersebut tentu belum dapat sepenuhnya mengukur kemampuan berpikir tingkat tinggi peserta didik pada ranah kemampuan menganalisis (C4), mengevalusi (C5), dan mengkreasi (C6). Masalah lain yang umum dilakukan sehingga membuat suatu instrumen tes tidak bersifat HOTS adalah bentuk instrumen tes yang diberikan pada peserta didik hanya berupa pernyataan-pernyataan yang berbentuk naratif yang kurang mampu menstimulus kemampuan berpikir tingkat tinggi peserta didik untuk memecahkan masalah dan berpikir kritis, misalnya instrumen tes yang umum digunakan berupa tes objektif (multiple choice dan essay) yang dikerjakan di kertas atau yang sering disebut dengan paper based test. Seperti yang dikatakan (Putri \& Raharjo, 2017) bahwa salah satu cara untuk mengembangkan kemampuan berpikir tingkat tinggi pada peserta 
didik adalah dengan membiasakan memberikan soal dalam bentuk pemecahan masalah, berpikir kreatif, dan berpikir kritis.

Berdasarkan hal tersebut perlu suatu instrumen tes HOTS yang mampu menstimulus kemampuan berpikir tingkat tinggi peserta didik. Instrumen tes HOTS yang dilengkapi dengan ilustrasi berupa wacana, gambar, grafik, video, animasi dan stimulasi interaktif serta pemberian feedback yang memanfaatkan masalah dalam kehidupan sehari-hari akan mampu menstimulus kemampuan berpikir tingkat tinggi peserta didik. Seperti yang dikatakan (Brookhart, 2010) bahwa untuk melaksanakan asesmen berpikir tingkat tinggi peserta didik adalah dengan cara pengamatan langsung dan pemberian umpan balik dengan peserta didik. Proses HOTS seharusnya dimulai dengan merangsang peserta didik untuk berpikir lebih aktif dari masalah sesuai dengan dimensi pengetahuan (faktual, konseptual, prosedural dan metakognitif) yang pernah dialami atau dapat dipikirkan para peserta didik (Anderson \& Krathwohl, 2010). Sebanyak 98\% guru merasa perlu dikembangkan instrumen tes HOTS berbasis CBT yang memungkinkan ilustrasi pada setiap butir soal berupa wacana, gambar, grafik, video, animasi dan stimulasi interaktif serta pemberian feedback untuk mengukur kemampuan berpikir tingkat tinggi peserta didik. Pembuatan instrumen tes yang dilengkapi dengan ilustrasi tersebut dapat dilakukan apabila memanfaatkan teknologi komputer sebagai media tes.

Penelitian ini perlu dilakukan agar dapat menciptakan model CBT yang tepat untuk memberikan stimulus HOTS pada peserta didik dalam mata pelajaran Fisika. Selain itu untuk mengetahui tipe soal, quiz dan setting juga question setting, membuat ilustasi soal fisika yang tepat dalam mengukur HOTS. Sehingga dari penelitian ini nantinya akan diketahui profil HOTS peserta didik dalam pembelajaran fisika yang telah diukur dengan menggunakan model CBT-HOTS yang telah dikembangkan. Kemudian dalam penelitian ini akan diukur juga validitas soal hasil pengembangan dan kepraktisan CBT dalam menjalankan asesmen HOTS.

Ada beberapa tujuan yang akan dicapai pada penelitian ini antara lain: (1) untuk mengembangkan model CBT untuk menstimulus HOTS peserta didik SMA dalam pembelajaran fisika; (2) untuk mengetahui tipe soal yang sesuai untuk mengukur HOTS; (3) untuk mengetahui quiz setting dan question setting yang sesuai untuk mengukur HOTS; (4) untuk mengetahui bentuk ilustrasi soal fisika SMA yang sesuai untuk mengukur HOTS; (5) untuk mengetahui profil HOTS peserta didik SMA dalam pembelajaran fisika yang diukur menggunakan model CBT HOTS hasil pengembangan; (6) untuk mengetahui validitas soal hasil pengembangan; (7) untuk mengetahui kepraktisan CBT dalam menjalankan asesmen HOTS.

HOTS atau dikenal dengan pola berpikir tingkat tinggi pada dasarnya merupakan tingkat pemikiran yang lebih tinggi, didasarkan pada hierarki pengolahan kemampuan kognitif. Test HOTS dapat dirancang dengan menampilkan konsep, visualisasi, analogi, dan kesimpulan (Schraw \& Robinson, 2011). Aspek yang paling penting dalam proses belajar mengajar yang efektif dan efisien adalah pendidik mampu mengembangkan kemampuan peserta didik untuk berpikir dan menguasaikonten materi. Tujuan proses belajar tersebut adalah untuk dapat mengembangkan dan meningkatkan HOTSpeserta didik yang telah menjadi tujuan utama pendidikan (Yen \& Halili, 2015). Seiring dengan perkembangan teknologi informasi dan komunikasi dalam aspek penilaian pembelajaran, perkembangan ini telah menghadirkan Ujian Berbasis Komputer atau lebih dikenal dengan CBT. CBT merupakan penggunaan komputer untuk mengendalikan baik analog, teknik pengujian dan evaluasi kualitas komponen dan produk maupun digital (Novrianti, 2014).

Hasil penelitian terkait yang pernah dilakukan, yaitu (1) Development of High Order Thinking Skill (HOTS) Oriented Cognitive Problems in Thermodynamics for Senior High Schools (Agustihana \& Suparno, 2019) metode penelitiannya yaitu peserta didik diberikan dua paket soal dalam bentuk multiple choice disertai alasan dan hasil penelitian yaitu berupa pengembangan instrumen fisika keterampilan berpikir 
tingkat tinggi siswa SMA pada materi Termodinamika; (2) The Analysis of students' higher order thinking skills (HOTS) in Wave and Optics Using IRT with winstep Software (Soeharto \& Rosmaiyadi, 2018), alat pengumpulan data berupa tes evaluasi HOTS untuk mengetahui HOTS dalam bentuk pilihan ganda beralasan dan hasil penelitian berupa analisis kemampuan berpikir tingkat tinggi pada materi gelombang dan optik menggunakan aplikasi IRT; (3) Pencapaian HOTS (Higher Order Thinking Skills) Mahasiswa Program Studi Pendidikan Fisika FKIP Universitas Samawa (Erfan \& Ratu, 2018), instrumen tes berupa soal uraian dikembangkan berdasarkan kisi-kisi yang mengacu pada kata kerja operasional tiap-tiap ranah kemampuan berpikir kognitif hasil pencapaian kemampuan berpikir tingkat tinggi (HOTS) mahasiswa yang masih rendah dan dominan pada kemampuan tingkat rendah (LOTS); (4) Constructing Multiple Choice Items to Measure Higher Order Thinking (Scully, 2017), hasil penelitian menyatakan bahwa soal multiple choice memiliki kapasitas untuk menilai keterampilan tingkat tinggi tertentu; (5) Pengembangan Instrumen Asesmen Pengetahuan Fisika Berbasis Komputer untuk Meningkatkan Kesiapan Peserta Didik dalam Menghadapi Ujian Nasional Berbasis Komputer (Istiyono \& Subroto, 2017), metode penelitian yaitu peserta didik diberikan paket soal berupa soal pilihan ganda yang terkemas dalam komputer dan hasil penelitiannya bertujuan menghasilkan instrumen penilaian berbasis computer; (6) Pengembangan Instrumen Tes Computer Based Test Higher Order Thinking (CBT-HOT) pada Mata Pelajaran Fisika di SMA (Himah et al., 2017), penelitian ini bertujuan menghasilkan produk Computer Based Test-Higher Order Thinking (CBT-HOT) dengan tipe soal multiple choice. Hasil dari penelitian yaitu bertujuan menghasilkan produk instrumen tes berbasis CBT yang valid dan praktis untuk mengukur kemampuan berpikir tingkat tinggi peserta didik. Namun dalam pengembangan instrumen tes tersebut karakteristik tipe soal yang digunakan sejauh ini hanya berkaitan dengan tipe soal tertentu atau konvensional, misalnya multiple choice dan essay serta tidak mempertimbangkan dimensi pengetahuan (faktual, konseptual, prosedural dan metakognitif). Soal multiple choice merupakan tipe soal yang paling umum digunakan dimana peserta tes diinstruksikan untuk memilih satu alternatif jawaban dari yang ditawarkan, namun hasil dari tes ini tidak serta merta menjamin kualitas yang baik yang mampu menarik kesimpulan yang valid dan dapat diandalkan dari skor tes (Osterlind, 2002).

Untuk itu perlu adanya asesmen HOTS model CBT inovatif dengan tipe-tipe soal yang sesuai untuk menstimulus keterampilan berpikir tingkat tinggi peserta didik pada mata pelajaran Fisika dengan menerapkan kompetensi dasar serta indikator-indikator dan memiliki karakteristik instrumen tes yang baik digunakan untuk penilaian sesuai dimensi pengetahuan dengan analisis kebutuhan di lapangan. Peneliti juga ingin mengetahui apakah suatu tipe soal mampu mempengaruhi kemampuan berpikir tingkat tinggi peserta didik, oleh karena itu peneliti mengembangkan soal tes ke dalam empat tipe soal yaitu true or false, multiple choice, fill in the blank, dan matching berbasis dimensi pengetahuan faktual, konseptual, procedural, dan metakognitif dengan ilustrasi berupa wacana, gambar, grafik, video, animasi dan stimulasi interaktif serta pemberian feedback. Selain itu, peneliti juga ingin mengetahui apakah quiz setting dan question setting dalam suatu soal tes dapat mempengaruhi kemampuan berpikir tingkat tinggi peserta didik.

\section{Metode}

Metode penelitian yang digunakan yaitu penelitian dan pengembangan (research and development). Penelitian ini menggunakan pendekatan mixed method yaitu pendekatan penelitian yang mengkombinasikan atau mengasosiasikan bentuk kualitatif dan bentuk kuantitatif (Creswell, 2013). Langkah-langkah penelitian dan pengembangan dapat dilihat pada Gambar 1 sebagai berikut (Borg and Gall, 1989): 


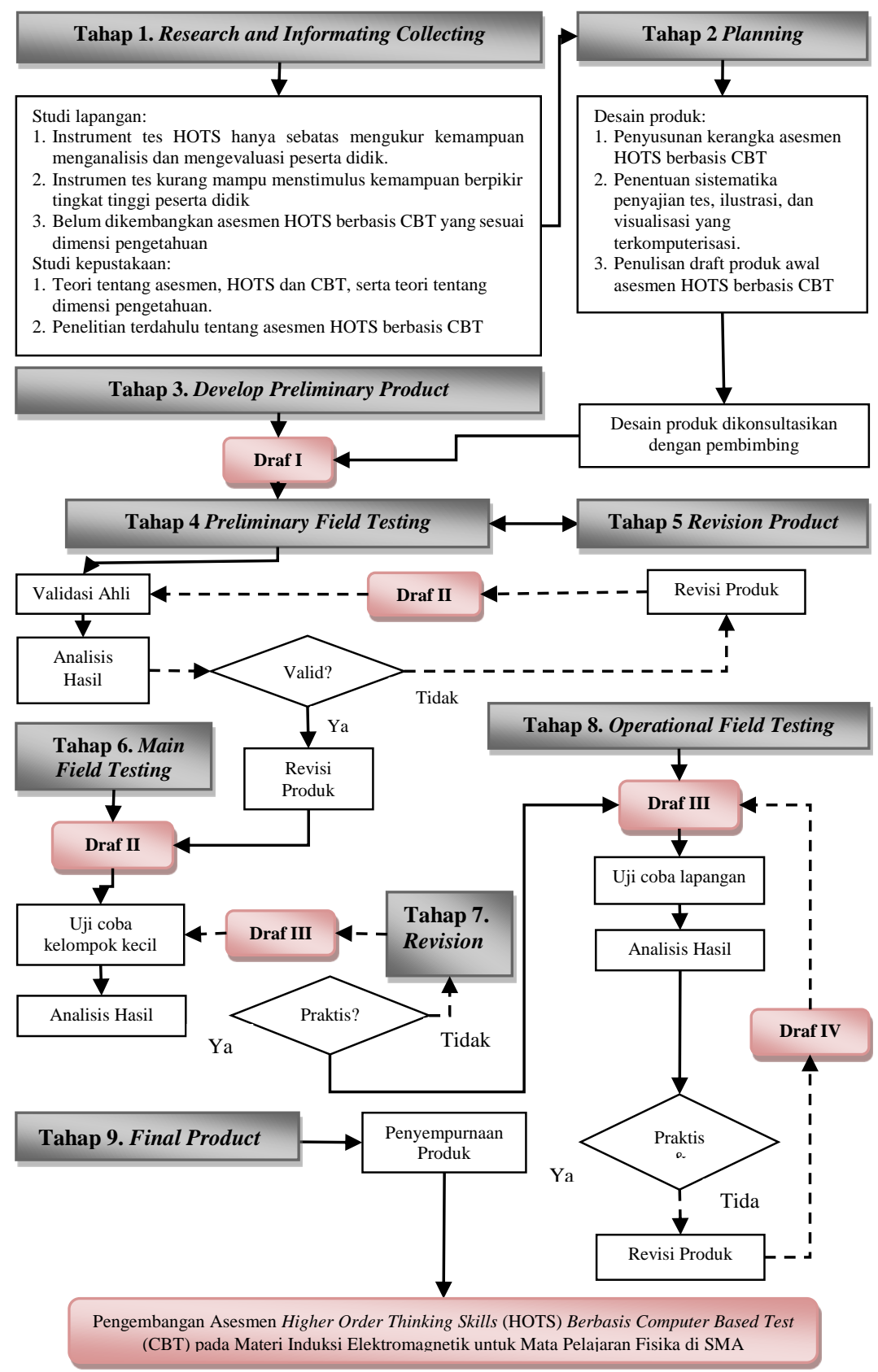

Gambar 1. Diagram Alir Penelitian dan Pengembangan

\section{Subjek Uji Coba Produk}

Subjek Uji Coba Produk dalam penelitian ini adalah seluruh peserta didik kelas XII SMA Negeri 1 Belitang tahun ajaran 2018/2019. Penelitian ini dilaksanakan pada tanggal 24-28 Februari 2020. Uji coba produk dilakukan di SMA Negeri 1 Belitang di kelas XII IPA 4 dan XII IPA 5 pada semester ganjil tahun pelajaran 2019/2020.Teknik pengambilan subjek uji coba produk pada penelitian ini adalah teknik cluster sampling yakni cara pengambilan sampel yang berdasarkan pada cluster-cluster tertentu (Sugiyono, 2017). Berdasarkan teknik pengambilan sampel di atas diperoleh sampel sebanyak dua kelas yaitu dengan 64 peserta didik yang akan dibagi menjadi empat kelompok sesuai dengan jumlah tipe soal HOTS.

\section{Teknik Pengumpulan Data}

Teknik pengumpulan data menggunakan lembar validasi ahli dan kuesioner responden. Validasi ahli melibatkan beberapa ahli untuk mengevaluasi produk awal yang dikembangkan peneliti. Alat pengumpul 
data yang digunakan berupa lembar validasi yang diberikan kepada ahli. Lembar validasi digunakan untuk mengumpulkan data berupa tanggapan dan saran-saran sebagai dasar untuk melakukan revisi produk awal. Data yang diperoleh dari para ahli didiskusikan sebagai acuan untuk merevisi produk sampai dinyatakan layak untuk diujicobakan. Validasi ini mencakup validasi materi, konstruksi, dan bahasa. Sedangkan kuesioner responden digunakan untuk mengukur kemampuan berpikir tingkat peserta didik dengan memberikan soal tes HOTS berbasis CBT dan membagikan kuesioner kepraktisan yang berkaitan dengan persepsi peserta didik terhadap produk Asesmen HOTS berbasis CBT. Kuesioner yang digunakan berupa pertanyaan tertutup, dalam bentuk check list dan responden terikat dengan pilihan jawaban seputar produk yang sedang dikembangkan oleh peneliti. Terdapat beberapa kuesioner yang digunakan pada penelitian, yakni:

1. Kuesioner Prapenelitian

Lembar kuesioner diberikan pada saat observasi awal untuk mengetahui kebutuhan dan permasalahan kemampuan HOTS peserta didik.

2. Kuesioner Validasi Produk

Pada kuesioner validasi materi, konstruksi dan bahasa pada asesmen HOTS berbasis CBT memuat pernyataan tertulis kepada tiga validator ahli. Kuesioner validasi bertujuan untuk memperoleh respons dari validator mengenai produk asesmen HOTS berbasis CBT yang sedang dikembangkan oleh peneliti. Hasil dari validator akan digunakan sebagai acuan apakah produk yang dikembangkan sudah valid atau belum valid.

a. Instrumen Soal HOTS Berbasis CBT

Instrumen ini digunakan untuk mengukur perubahan kemampuan berpikir tingkat tinggi peserta didik. Instrumen yang dibuat peneliti telah menyesuaikan indikator HOTS.

b. Kuesioner Respons Peserta Didik

Kuesioner respons peserta didik digunakan untuk mengumpulkan pendapat mengenai respons peserta didik terhadap kepraktisan asesmen HOTS berbasis CBT.

\section{Analisis Data}

Instrumen untuk pengumpulan data dalam penelitian ini adalah (1) analisis kuesioner pra penelitian, dimana data yang diperoleh dari hasil kuesioner pra penelitian dianalisis secara deskriptif kualitatif, sehingga ditemukan masalah kemampuan berpikir tingkat tinggi akan kebutuhan tes HOTS berbasis CBT; (2) analisis kuesioner validasi ahli, dimana nilai rata-rata setiap pernyataan didapat dari jumlah total skor responden dibagi banyak responden dengan format penilaian menggunakan skala Likert lima poin; (3) kuesioner respons pendidik dan peserta didik, data yang diperoleh dianalisis menggunakan skala likert lima poin dan dipersentasekan setiap alternatif jawaban yang dicapai. Untuk tanggapan atau pendapat pendidik dan peserta didik dilihat dari hasil persentase setiap pernyataan. Data yang diperoleh dari kuesioner dan keterampilan komunikasi ilmiah dianalisis menggunakan skala rating. Kemudian untuk menganalisis setiap pernyataan atau indikator, kemudian menghitung frekuensi jawaban setiap kategori (pilihan jawaban) dan jumlahkan. 


\section{Hasil dan Pembahasan}

\section{Hasil Pengembangan (Development)}

Produk asesmen HOTS berbasis CBT dapat dilihat pada Gambar 2 berikut.

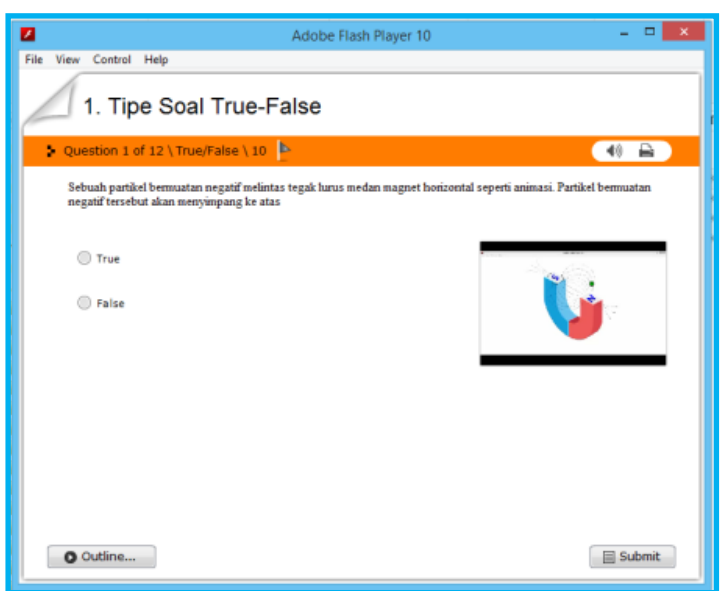

Tipe Soal True/False

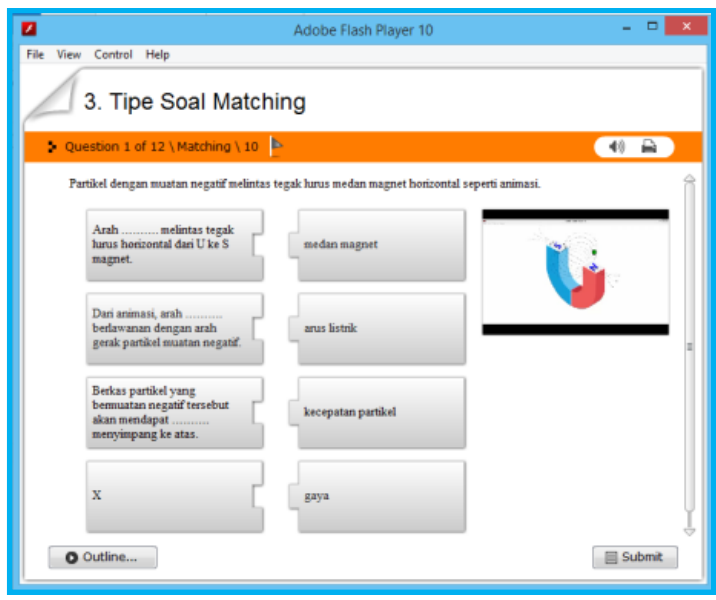

Tipe Soal Matching

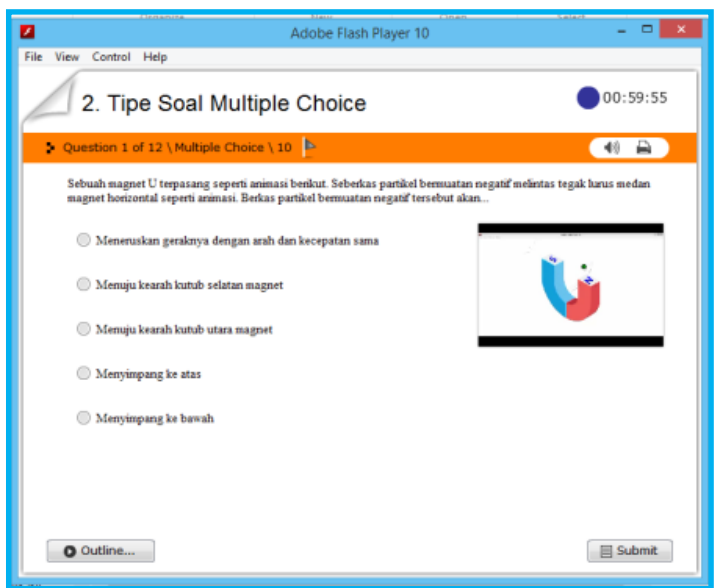

Tipe Soal Multiple Choice

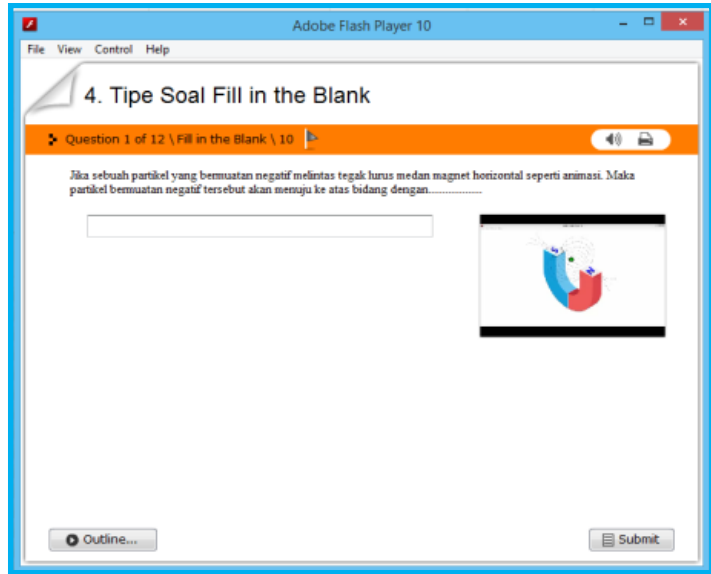

Tipe Soal Fill in the Blank

Gambar 2. Produk Asesmen HOTS berbasis CBT

\section{Uji Validasi}

Untuk validasi pengembangan asesmen HOTS berbasis CBT pada materi induksi elektromagnetik ada dua aspek yang divalidasi yaitu aspek content (materi, konstruksi, bahasa) dan aspek layout (ilustrasi, tipe soal, dan quiz setting, question setting). Lihat Tabel 1 berikut. 
Tabel 1. Validasi Ahli pada Asesmen HOTS Berbasis CBT

\begin{tabular}{|c|c|c|c|}
\hline No & Indikator /Aspek yang Dinilai & Rerata Skor & $\%$ \\
\hline \multirow[t]{8}{*}{1} & AspekMateri & & \\
\hline & Tingkat kesesuaian soal dengan indikator & 4,00 & 80 \\
\hline & Tingkat kemenarikan stimulus & 4,12 & 82 \\
\hline & Tingkat kesesuaian bentuk stimulus & 3,96 & 79 \\
\hline & Tingkat kesesuaian soal dalam mengukur level kognitif penalaran & 3,92 & 78 \\
\hline & Kesesuaian dimensi pengetahun dengan indikator dan soal & 3,74 & 75 \\
\hline & Tingkat kehomogenan dan kelogisan pilihan jawaban & 3,94 & 79 \\
\hline & Rerata Aspek Materi & 3,95 & 79 \\
\hline \multirow[t]{7}{*}{2} & Aspek Konstruksi & & \\
\hline & Pokok soal dirumuskan dengan singkat, jelas, dan tegas. & 3,73 & 75 \\
\hline & $\begin{array}{l}\text { Rumusan soal dan pilihan jawaban merupakan pernyataan yang diperlukan } \\
\text { saja. }\end{array}$ & 3,83 & 77 \\
\hline & Pokok soal tidak memberi petunjuk ke kunci jawaban. & 3,85 & 77 \\
\hline & Pokok soal bebas dari pernyataan yang bersifat negatif ganda. & 3,83 & 77 \\
\hline & Gambar, grafik, tabel, diagram, atau sejenisnya jelas dan berfungsi. & 3,91 & 78 \\
\hline & Rerata Aspek Konstruksi & 3,85 & 77 \\
\hline \multirow[t]{6}{*}{3} & Aspek Bahasa & & \\
\hline & Kesesuaian penggunaan bahasa dengan kaidah bahasa Indonesia. & 3,96 & 79 \\
\hline & Tidak menggunakan bahasa yang berlaku setempat. & 4,14 & 83 \\
\hline & Soal menggunakan kalimat yang komunikatif. & 4,40 & 88 \\
\hline & Pilihan jawaban tidak mengulang kata, kecuali satu kesatuan pengertian. & 4,19 & 84 \\
\hline & Rerata Aspek Bahasa & 4,17 & 83 \\
\hline \multirow[t]{5}{*}{4} & Aspek Ilustrasi, Tipe Soal, dan Quiz and Question Setting & & \\
\hline & Tipe soal & 4,17 & 83 \\
\hline & Stimulus & 4,40 & 88 \\
\hline & Setting CBT & 4,07 & 81 \\
\hline & Rerata Aspek Ilustrasi, Tipe Soal, dan Quiz and Question Setting & 4,21 & 84 \\
\hline \multicolumn{2}{|r|}{ Rerata Keseluruhan Hasil Penilaian } & 4,04 & 81 \\
\hline
\end{tabular}

Keseluruhan hasil penilaian validasi asesmen HOTS berbasis CBT pada materi induksi elektromagnetik dari validator adalah sebesar $81 \%$ artinya bahwa materi, konstruksi, bahasa dan ilustrasi yang sudah dirancang oleh peneliti sudah valid. Meskipun ahli sudah menyatakan produk yang kembangkan sudah valid dan dapat digunakan untuk penelitian, sebelumnya ahli juga memberikan kritik dan saran. Selain itu ada saran dari praktisi pada tipe soal matching agar pilihan jawaban ditambah sebagai pengecoh dan setiap jawaban yang benar diberi skor. Lihat Gambar 3 berikut.

Sebelum Revisi

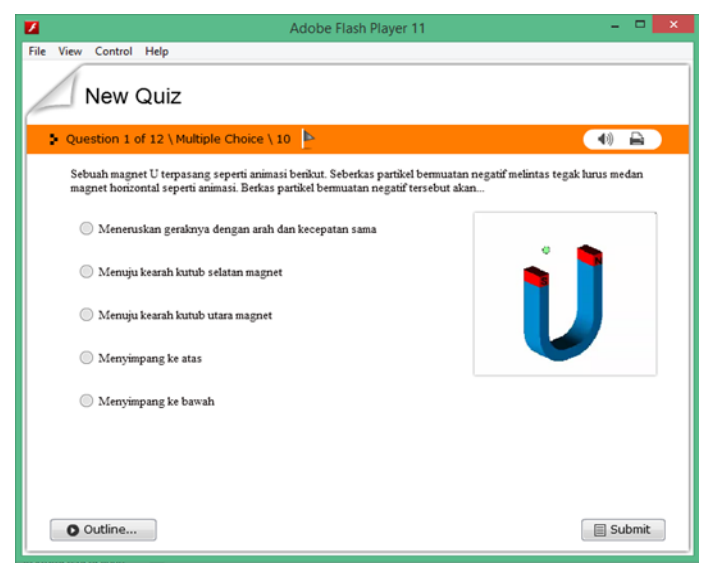

Setelah Revisi

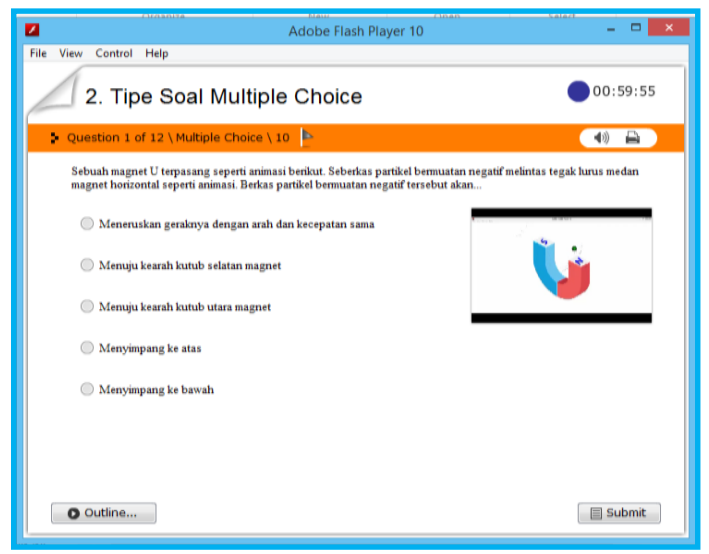

Gambar 3. Revisi Hasil Validasi Ahli Materi, Konstruksi dan Bahasa 
Hasil rekapitulasi uji validasi materi, konstruksi, dan bahasa rata-rata validasi materi pada tipe soal true or false, multiple choice, fill in the blank, dan matching secara berturut-turut yaitu $80 \%, 80 \%, 78 \%$ dan $78 \%$ yang artinya semua tipe soal memiliki validasi materi yang valid. Rata-rata validasi konstruksi pada tipe soal true or false, multiple choice, fill in the blank, dan matching secara berturut-turut yaitu 77\%, 77\%, 76\% dan $76 \%$ yang artinya semua tipe soal memiliki validasi konstruksi yang valid. Adapun rata-rata validasi bahasa pada tipe soal true or false, multiple choice, fill in the blank, dan matching secara berturut-turut yaitu $84 \%, 83 \%, 83 \%$ dan $83 \%$ yang artinya semua tipe soal memiliki validasi bahasa yang valid.

Berdasarkan rekapitulasi hasil uji validasi ahli (ilustrasi, tipe soal, dan quiz and question) setting CBT dalam pengaturan waktu dan pengacakan soal dan jawaban dinilai ahli baik dalam membantu menstimulus HOTS peserta didik, dan untuk setting CBT dalam pengaturan answer submition dinilai ahli baik untuk menstimulus HOTS peserta didik, serta setting CBT dalam pengaturan umpan balik dinilai cukup baik dalam menstimulus HOTS peserta didik begitupun untuk setting CBT dalam pengaturan penyekoran dan pembobotan yang juga dinilai baik oleh seluruh ahli dalam menstimulus HOTS peserta didik. Sedangkan dapat diketahui bahwa praktisi menilai setting CBT dalam pengaturan waktu pengerjaan soal sudah baik, setting CBT dalam pengaturan pengacakan soal dan jawaban, dan menilai baik pada setting CBT dalam pengaturan answer sibmition untuk menstimulus HOTS peserta didik. Begitupun dengan setting CBT pengaturan umpan balik yang dinilai sangat baik oleh praktisi dalam menstimulus HOTS peserta didik. Sedangkan untuk setting CBT dalam pengaturan penyekoran dan pembobotan praktisi menilai baik dalam menstimulus HOTS peserta didik.

\section{Implementasi}

Hasil uji coba pada 64 siswa yang dibagi empat kelompok yang telah dilakukan kemudian dianalisis menggunakan statistik One Way Anova untuk melihat perbedaan hasil uji coba terhadap empat tipe soal tersebut. Berikut adalah hasil uji yang telah dilakukan oleh peneliti sebagaimana terlihat pada Tabel 2.

Tabel 2. Hasil Uji Distribusi Normal

One-Sample Kolmogorov-Smirnov Test

\begin{tabular}{llrrrr}
\hline & & $\begin{array}{c}\text { Hasil Tes } \\
\text { True or False }\end{array}$ & $\begin{array}{c}\text { Hasil Tes } \\
\text { Multiple } \\
\text { Choice }\end{array}$ & $\begin{array}{c}\text { Hasil Tes Fill } \\
\text { in the Blank }\end{array}$ & $\begin{array}{c}\text { Hasil Tes } \\
\text { Matching }\end{array}$ \\
\hline $\mathrm{N}$ & Mean & 16 & 16 & 16 & 16 \\
Normal Parameters, & 88,00 & 72,25 & 64,56 & 63,00 \\
& Std. & 9,209 & 11,311 & 7,266 & 5,514 \\
& Deviation & & & & \\
Most Extreme Differences & Absolute & 0,206 & 0,179 & 0,254 & 0,318 \\
& Positive & 0,206 & 0,179 & 0,254 & 0,318 \\
Kolmogorov-Smirnov $Z$ & Negative & $-0,168$ & $-0,104$ & $-0,194$ & $-0,266$ \\
Asymp. Sig. (2-tailed) & & 0,826 & 0,715 & 1,017 & 1,271 \\
\hline
\end{tabular}

a. Test distribution is Normal.

b. Calculated from data.

Berdasarkan hasil output uji normal Tabel 2 diperoleh nilai dari hasil tes true or false, multiple choice, fill in the blank dan matching bernilai lebih besar dari 0,05 . Maka $\mathrm{H}_{0}$ diterima yang artinya keempat sampel (hasil tes) yang diperoleh dari populasi berdistribusi normal.

Selanjutnya dilakukan uji statistik menggunakan One Way Anova dengan test of homogeneity of variances seperti pada Tabel 3 dan uji Anova seperti pada Tabel 4: 
Tabel 3. Hasil Uji Homogenitas

Test of Homogeneity of Variances

Nilai

\begin{tabular}{ccccccr}
\hline Levene Statistic & df1 & & df2 & Sig. \\
\hline & 2,624 & & 3 & & 60 & 0,059 \\
\hline
\end{tabular}

Tabel 4. Hasil Uji Anova

\begin{tabular}{lrrrrr} 
Nilai & \multicolumn{1}{c}{ ANOVA } & & \\
\hline & Sum of Squares & Df & Mean Square & F & Sig. \\
\hline Between Groups & 6277,922 & 3 & 2092,641 & 28,286 & 0,000 \\
Within Groups & 4438,938 & 60 & 73,982 & & \\
Total & 10716,859 & 63 & & & \\
\hline
\end{tabular}

Berdasarkan hasil output Test of Homogenity of Variances pada Tabel 3 diperoleh nilai signifikansi sebesar 0,059. Oleh karena itu nilai signifikansinya lebih besar dari 0,05 , sehingga $\mathrm{H}_{0}$ diterima yang artinya keempat sampel (hasil tes) memiliki varians yang homogen. Berdasarkan hasil output Anova pada Tabel 4 diperoleh nilai signifikansi sebesar 0,000. Oleh karena nilai signifikansi lebih kecil dari 0,05 , maka $\mathrm{H}_{0}$ ditolak yang artinya terima $\mathrm{H}_{1}$ hasil ini menunjukkan ada perbedaan rata-rata hasil tes peserta didik atas perbedaan tipe soal true or false, multiple choice, fill in the blank dan matching.

Tabel 5. Hasil Tes HOTS berbasis CBT Peserta Didik

\begin{tabular}{|c|c|c|c|}
\hline \multirow{5}{*}{ Profil } & & True or False & 100 \\
\hline & Nilai Tertinggi & $\begin{array}{c}\text { Multiple Choice } \\
\text { Fill in the Blank } \\
\text { Matching }\end{array}$ & $\begin{array}{l}100 \\
83 \\
75\end{array}$ \\
\hline & Nilai Terendah & $\begin{array}{c}\text { True or False } \\
\text { Multiple Choice } \\
\text { Fill in the Blank } \\
\text { Matching }\end{array}$ & $\begin{array}{l}75 \\
58 \\
58 \\
58\end{array}$ \\
\hline & Rata-rata Nilai & $\begin{array}{c}\text { True or False } \\
\text { Multiple Choice } \\
\text { Fill in the Blank } \\
\text { Matching }\end{array}$ & $\begin{array}{l}88,00 \\
72,25 \\
64,56 \\
63,00\end{array}$ \\
\hline & Standar Deviasi & $\begin{array}{c}\text { True or False } \\
\text { Multiple Choice } \\
\text { Fill in the Blank } \\
\text { Matching }\end{array}$ & $\begin{array}{c}9,209 \\
11,311 \\
7,266 \\
5,514\end{array}$ \\
\hline
\end{tabular}

Berdasarkan Tabel 5. Standar deviasi setiap tipe soal bervariasi. Hasil tes menggunakan tipe soal multiple choice memiliki standar deviasi paling tinggi sedangkan tipe soal matching memiliki standar deviasi paling rendah. Artinya semakin rendah hasil standar deviasi maka semakin mendekati rata-rata, sedangkan jika nilai standar deviasi semakin tinggi maka semakin lebar juga rentang variasi datanya. Sehingga nilai rata-rata dapat digunakan sebagai representasi dari keseluruhan sebaran data. 
Tabel 6. Rekapitulasi Hasil Kepraktisan Produk

\begin{tabular}{ccccccc}
\hline Aspek & $\begin{array}{c}\text { True or } \\
\text { False }\end{array}$ & $\begin{array}{c}\text { Multiple } \\
\text { Choice }\end{array}$ & $\begin{array}{c}\text { Fill in the } \\
\text { Blank }\end{array}$ & Matching & $\begin{array}{c}\text { Rata- } \\
\text { rata }\end{array}$ & $\begin{array}{c}\text { Persentase } \\
\text { (\%) }\end{array}$ \\
\hline Kemudahan & 4,52 & 4,54 & 4,29 & 4,27 & 4,41 & 88,13 \\
Pengoprasian & & & & & & \\
Keterbacaan & 4,43 & 4,32 & 4,26 & 4,28 & 4,32 & 86,46 \\
Kemenarikan & 4,47 & 4,22 & 4,26 & 4,17 & 4,22 & 84,48 \\
Keefektifan & 4,33 & 4,42 & 4,13 & 4,17 & 4,26 & 85,19 \\
Keefisienan & 4,45 & 4,44 & 4,50 & 4,49 & 4,47 & 89,48 \\
Rata-rata & 4,44 & 4,40 & 4,27 & 4,27 & & \\
Persentase (\%) & 88,76 & 87,94 & 85,42 & 85,37 & & 86,75 \\
\hline
\end{tabular}

Pengamatan terhadap kegiatan pelaksanaan tes dilakukan oleh peneliti saat implementasi berlangsung, lalu peneliti membagikan kuesioner responden kepada peserta didik mengenai tanggapan terhadap produk asesmen HOTS berbasis CBT yang sedang dikembangkan. Hasil kepraktisan yang diperoleh dapat dilihat pada Tabel 6 dimana hasil responden terhadap kepraktisan produk asesmen HOTS berbasis CBT untuk semua tipe soal memiliki tingkat pencapaian sebesar $80 \%<\mathrm{P} \leq 100 \%$ dengan kategori sangat baik, artinya produk asesmen HOTS berbasis CBT dinyatakan sangat praktis.

\section{Model CBT untuk Menstimulus HOTS Peserta Didik}

Berdasarkan hasil uji tipe soal, ilustrasi, dan quiz and question setting mampu menstimulus HOTS peserta didik. Tipe soal true or false, multiple choice, fill in the blank dan matching memiliki tingkat kelayakan yang cocok untuk menstimulus HOTS peserta didik dengan persentase berturut-turut $80 \%, 80 \%, 87 \%$ dan 93\%. Hal ini sependapat dengan (King et al., 2010) yang menyatakan bahwa ada tiga bentuk tugas yang berguna dalam mengukur HOTS peserta didik, yaitu: (a) soal pilihan (true or false), pilihan ganda (multiple choice), menjodohkan (matching) dan penyortiran; (b) jawaban singkat/esai (fill in the blank), dan kinerja; dan (c) menjelaskan dan memberikan alasan jawaban yang dipilih.

Ilustrasi yang telah dipilih dan digunakan untuk menunjang kelayakan tipe soal (true or false, multiple choice, fill in the blank, dan matching) untuk menstimulus HOTS peserta didik yang diperoleh dari pendapat responden, yaitu wacana memiliki persentase sebesar 93\%, gambar sebesar 93\%, video sebesar $87 \%$, dan animasi sebesar $87 \%$, sedangkan simulasi termasuk grafik dan tabel hasil percobaan sebesar $80 \%$. Dapat disimpulkan bahwa semua ilustrasi dikatakan cocok dan berpotensi untuk menunjang kelayakan tipe soal dalam menstimulus HOTS peserta didik. Hal tersebut sependapat dengan (Suyatna et al., 2020) bahwa stimulus pertanyaan HOTS dalam bentuk gambar, grafik, video, audio, animasi, simulasi interaktif dapat memperkaya keragaman pertanyaan.

Quiz and question setting yang diatur untuk menjalankan produk yang telah dikembangkan seperti pengaturan waktu yang ditampilkan pada layar komputer disarankan oleh responden untuk menampilkan sisa waktu pengerjaan dengan mendapatkan nilai persentase sebesar $80 \%$, pengacakan soal dan jawaban untuk mendapatkan keberagaman jawaban mendapatkan persetujuan dari responden dengan persentase sebesar $80 \%$, pengaturan answes submition dimana peserta didik diberikan kesempatan untuk mengulang tes atau memilih soal yang ingin dikerjakan terlebih dahulu mendapatkan persetujuan responden dengan persentase sebesar $80 \%$, pengaturan feedback diberikan di setiap soal sebagai informasi materi pertanyaan yang belum dikuasai dalam menindaklanjuti peserta didik yang menjawab salah sedangkan untuk peserta didik yang menjawab dengan benar maka feedback yang diberikan berupa motivasi dan pengayaan materi mendapat persetujuan dari responden sebesar $87 \%$, dan pengaturan penyekoran dan pembobotan dibedakan berdasarkan tingkat berpikir, tingkat kesukaran soal dan tipe soal (true or false, multiple choice, fill in the blank dan matching) mendapatkan persetujuan dari responden sebesar $80 \%$. 
Hal tersebut sesuai dengan yang dinyatakan oleh (Suyatna et al., 2020) bahwa item HOTS perlu mengandung rangsangan untuk mendorong kemampuan berpikir peserta didik, seperti stimulus HOTS dalam bentuk gambar, grafik, fenomena, video, audio, simulasi, animasi, eksperimental dapat memperkaya keragaman item, tingkat berpikir kognitif, dan stimulus dalam bentuk video, audio, animasi, simulasi interaktif sangat mendukung dalam penilaian pembelajaran dan mengurangi verbalisme tentang pertanyaan tes. Berdasarkan pernyataan di atas, diperoleh kesimpulan bahwa model CBT yang dikembangkan sudah mengandung stimulus yang tepat dan mampu mendorong peserta didik untuk berpikir HOTS.

\section{Tipe Soal yang Sesuai untuk Mengukur HOTS}

Grafik yang ditampilkan pada Gambar 4 menunjukkan hasil tes menggunakan produk asesmen HOTS berbasis CBT pada materi induksi elektromagnetik untuk mata pelajaran fisika di SMA.

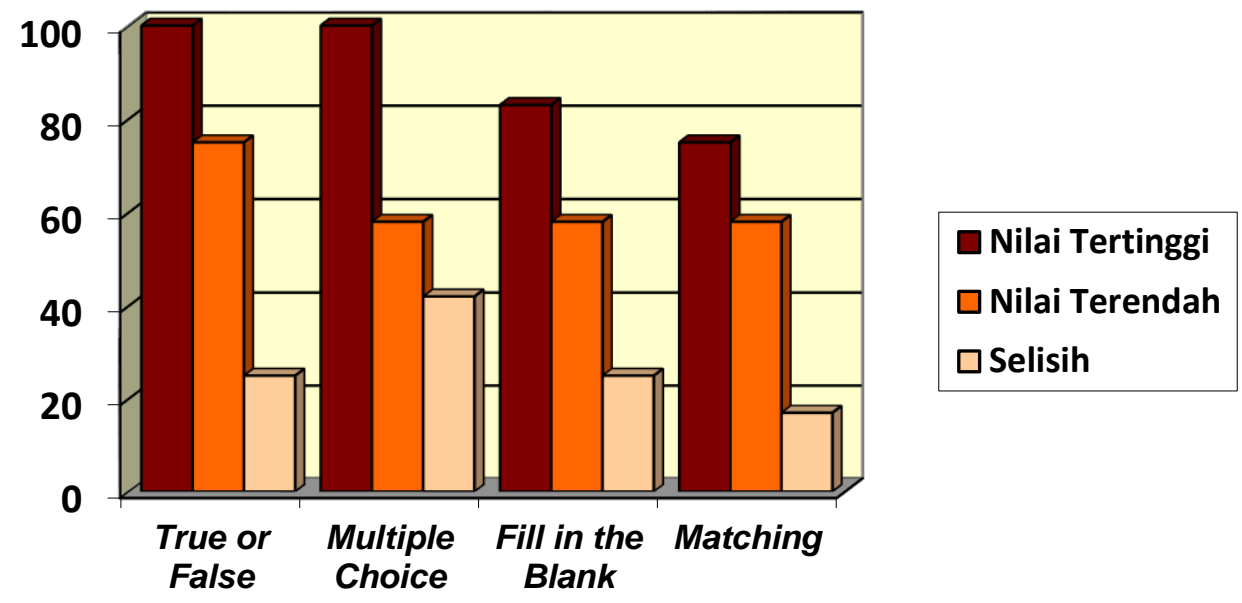

Gambar 4. Hasil Tes Asesmen HOTS Berbasis CBT

Berdasarkan Gambar 4 dapat diketahui bahwa pencapaian hasil tes pada tipe soal true or false dinilai cukup baik dalam menstimulus HOTS peserta didik. Hasil tes pada tipe soal multiple choice dinilai cukup baik dalam menstimulus HOTS peserta didik. Hasil tes pada tipe soal fill in the blank dinilai baik dalam menstimulus HOTS peserta didik. Sedangkan hasil tes pada tipe soal matching dinilai sangat baik dalam menstimulus HOTS peserta didik. Tipe soal fill in the blank dan matching memiliki tingkat kesulitan yang mampu menstimulus HOTS peserta didik karena dalam menyelesaikan soal fill in the blank peserta didik tidak disediakan jawaban sehingga dalam menjawab soal peserta didik tidak dapat menjawab dengan jawaban di luar konsep materi.

Tipe soal fill in the blank memerlukan kemampuan peserta didik dalam mengeksplorasi pengetahuan yang lebih banyak tentang sumber-sumber belajar dan fenomena alam yang sesuai dengan permasalahan tertentu sebagai proses pembelajaran. Hal tersebut sependapat dengan (Ikhwan et al., 2015) bahwa fill in the blank merupakan tipe soal yang cocok dan efektif untuk menilai dan melatih kemampuan eksplorasi fenomena fisika. Sedangkan tipe soal matching cocok sebagai tipe soal yang sesuai untuk mengukur HOTS peserta didik karena pada tipe soal matching peserta didik harus menjodohkan semua pertanyaan dan pilihan jawaban dengan tepat. Namun apabila peserta didik dalam menjodohkan pertanyaan dengan jawaban ada salah satu jawaban yang tidak tepat dengan pertanyaan, maka peserta didik tidak akan mendapatkan skor. Hal tersebut sependapat dengan (Jancarík \& Kostelecká, 2015) bahwa matching merupakan tipe soal yang sangat cocok untuk menilai tingkat pengetahuan yang telah dicapai oleh peserta didik dan sangat baik dalam membedakan tingkat pengetahuan yang diukur dengan skor kelulusan. 
Hal tersebut berbeda dengan tipe soal true or false dan multiple choice yang dimana peserta didik hanya perlu mencari satu jawaban yang benar. Tipe soal true or false dan multiple choice dapat melatih kemampuan eksplorasi fenomena fisika peserta didik dengan bantuan ilustrasi soal yang mampu menstimulus kemampuan berpikir peserta didik, namun pada umumnya tipe soal true or false kurang cocok untuk mengukur kemampuan menganalisis suatu permasalahan karena peluang memilih jawaban benar sama dengan peluang memilih jawaban salah sehingga dapat mendorong peserta didik untuk menebak jawaban walaupun mereka tidak mengetahui jawaban mana yang benar. Sedangkan tipe soal multiple choice kurang efektif untuk mengukur tipe pertanyaan yang membuthkan sebuah proses berpikir seperti pemecahan masalah, kemampuan mengorganisir masalah, dan mengekspresikan ide karena jawaban sudah tersedia dengan peluang sama untuk masing-masing jawaban. Hal tersebut sependapat dengan (Suyatna et al., 2020) bahwa tipe soal true or false dan multiple choice termasuk jenis pertanyaan yang memiliki tahapan berpikir yang berbeda penyelesaian. Tipe soal true or false hanya memiliki peluang $50 \%$ salah, sedangkan tipe soal multiple choice dengan lima pilihan jawaban, memiliki peluang $20 \%$ kemungkinan menjawab dengan benar.

\section{Quiz Setting dan Question Setting yang Sesuai untuk Mengukur HOTS}

Pengaturan waktu dinilai baik dalam membatasi pengerjaan soal. Menurut ahli, pengaturan waktu dapat disediakan pada masing-masing soal sesuai dengan tingkat kesulitan dan proses pengerjaan soal tersebut. Pengaturan random soal dan jawaban dinilai baik dalam mencegah kecurangan yang dilakukan peserta didik ketika melakukan tes.

Hal tersebut sependapat dengan (Gunawan \& Prabowo, 2017) bahwa pengacakan soal yang dilakukan akan membuat soal-soal yang dikerjakan peserta didik tidak sama dengan yang lainnya (acak) sehingga proses pengerjaan tes lebih kondusif dan mampu mencegah kecurangan. Pengaturan answer submition dinilai baik untuk menstimulus HOTS peserta didik, pengaturan umpan balik dinilai baik oleh ahli 1 dan ahli 2, sedangkan praktisi menilai sangat baik dalam menstimulus HOTS peserta didik untuk mengembangkan pemahaman konsep materi induksi elektromagnetik. Begitupun pada pengaturan penyekoran dan pembobotan soal yang telah disesuaikan dengan ranah kognitif dan tingkat kesukaran soal maka dinilai baik oleh semua ahli dan praktisi dalam menstimulus HOTS peserta didik.

\section{Bentuk Ilustrasi Soal Fisika SMA yang Sesuai untuk Mengukur HOTS}

Berdasarkan penilaian yang telah dilakukan oleh validator, ilustrasi yang sesuai untuk menstimulus HOTS peserta didik yaitu wacana, gambar, video, animasi dan simulasi yang mengkaitkan fenomenafenomena yang ada dengan kehidupan sehari-hari. Hal tersebut sesuai dengan pendapat (Novrianti, 2014) bahwa penggunaan CBT dalam pelaksanaan evaluasi dapat memberikan rangsangan berpikir kepada peserta didik melalui dukungan animasi, gambar, musik, foto, video tutorial dan tes yang menarik sehingga peserta didik dapat melihat secara langsung skor yang dicapainya melalui display komputer.

\section{Profil HOTS Peserta Didik Diukur dengan HOTS Berbasis CBT}

Dari empat tipe soal HOTS yang diujikan, persentase peserta didik dengan tipe soal true or false yang mendapat nilai di atas KKM adalah sebesar $100 \%$ dengan rata-rata nilai 88,00 . Untuk nilai tertinggi adalah 100 dan nilai terendah adalah 75 . Persentase peserta didik dengan tipe soal multiple choice yang mendapat nilai di atas KKM adalah sebesar 50\% dengan rata-rata nilai 72,25. Untuk nilai tertinggi adalah 100 dan nilai terendah adalah 58. Persentase peserta didik dengan tipe soal fill in the blank yang mendapat nilai di atas KKM adalah sebesar 12,50\% dengan rata-rata nilai 64,56. Untuk nilai tertinggi adalah 83 dan nilai terendah adalah 58. Sedangkan persentase peserta didik dengan tipe soal matching yang mendapat nilai di atas KKM adalah sebesar 6,25\% dengan rata-rata nilai 63,00. Untuk nilai tertinggi adalah 75 dan nilai terendah adalah 58. Dari hasil uji statistic One Way Anova menunjukkan bahwa ada 
rata-rata hasil tes peserta didik yang berbeda berdasarkan empat tipe soal (true or false, multiple choice, fill in the blank dan matching). Artinya setiap tipe soal mampu mengukur HOTS peserta didik.

\section{Validitas Asesmen HOTS Berbasis CBT}

Hasil validator terhadap kevalidan produk asesmen HOTS berbasis CBT dimana aspek materi mendapatkan persentase sebesar $79 \%$ dan aspek konstruksi mendapatkan persentase sebesar $77 \%$. Artinya aspek materi dan aspek konstruksi memiliki tingkat pencapaian sebesar $60 \%<\mathrm{V} \leq 100 \%$ dengan kategori valid. Sedangkan untuk aspek bahasa mendapatkan persentase sebesar $83 \%$ dan aspek ilustrasi, tipe soal quiz and question setting mendapatkan persentase sebesar $84 \%$. Artinya aspek bahasa dan aspek ilustrasi, tipe soal, quiz and question setting memiliki tingkat pencapaian sebesar $80 \%<\mathrm{V} \leq 100 \%$ dengan kategori sangat valid. Hal tersebut sesuai dengan (Arikunto, 2012) yang menyatakan bahwa untuk menguji validitas setiap butir soal maka skor-skor yang ada pada butir soal yang dimaksud dikorelasikan dengan skor totalnya, dengan diperolehnya indeks validitas setiap butir soal, maka dapat diketahui butirbutir soal manakah yang memenuhi syarat dilihat dari indeks validitasnya. Sehingga validasi asesmen HOTS berbasis CBT pada materi induksi elektromagnetik untuk mata pelajaran fisika di SMA ini sudah terpenuhi.

\section{Kepraktisan Asesmen HOTS Berbasis CBT}

Adapun kepraktisan asesmen HOTS berbasis CBT dilakukan mencakup beberapa kriteria berikut, yaitu:

1. Asesmen HOTS berbasis CBT ini didasarkan pada dimensi pengetahuan yang disesuaikan dengan tipe soal yang berbeda namun tidak terlepas dari kebutuhan karakteristik dari materi.

2. Asesmen HOTS berbasis CBT ini dilengkapi wacana, gambar, video, animasi dan simulasi yang mampu memberikan stimulus kepada peserta didik dalam memahami maksud soal yang bersifat abstrak.

3. Dapat menstimulus kemampuan berpikir tingkat tinggi peserta didik.

4. Mudah digunakan oleh peserta didik ataupun pendidik/guru (praktis).

Berdasarkan hasil tes HOTS berbasis CBT peserta didik yang dikembangkan dengan persentase tipe soal true or false, multiple choice, fill in the blank, matching berturut-turut adalah 88,76\%, 87,94\%, 85,42\% dan 85,37\%. Hasil responden terhadap kepraktisan produk asesmen HOTS berbasis CBT untuk semua tipe soal memiliki tingkat pencapaian sebesar $80 \%<\mathrm{P} \leq 100 \%$ dengan kategori sangat baik. Artinya peserta didik sangat tertarik dan tidak mengalami kendala, dan produk dinyatakan praktis maka kepraktisan produk asesmen HOTS berbasis CBT pada mata pelajaran induksi elektromagnetik sudah terpenuhi. Hal ini sesuai dengan pendapat (Sugiyono, 2015) bahwa rating scale bersifat fleksibel, tidak terbatas hanya pengukuran sikap saja tetapi bisa juga mengukur persepsi responden terhadap fenomena dengan pengukuran menggunakan indikator-indikator atau aspek-aspek yang akan dinilai.

\section{Kesimpulan}

Model CBT yang dikembangkan perlu mengandung stimulus yang tepat dan mampu mendorong peserta didik untuk berpikir HOTS, seperti wacana, gambar, video, animasi dan simulasi (termasuk grafik, fenomena dan eksperimental) dapat memperkaya keragaman pertanyaan, tingkat berpikir kognitif, dan mengurangi verbalisme dalam pertanyaan. Tipe soal true or false, multiple choice, fill in the blank, dan matching valid dan praktis untuk mengukur dan menstimulus HOTS peserta didik pada materi induksi elektromagnetik untuk mata pelajaran fisika di SMA karena mampu menggambarkan pengetahuan faktual, konseptual, procedural, dan metakognitif sesungguhnya yang dikuasai oleh peserta didik. 
Setting yang sesuai untuk mengukur asesmen HOTS berbasis CBT adalah dengan pengaturan waktu yang menampilkan sisa waktu pengerjaan tes. Pertanyaan dan jawaban asesmen HOTS berbasis CBT diatur secara acak. Setiap pertanyaan harus diukur sesuai dengan tingkat berpikir, tingkat kesulitan pertanyaan, dan jenis pertanyaan. Pengaturan feedback diberikan di setiap soal sebagai informasi materi pertanyaan yang belum dikuasai dalam menindaklanjuti peserta didik yang menjawab salah sedangkan untuk peserta didik yang menjawab dengan benar maka feedback yang diberikan berupa motivasi dan pengayaan materi.

Ilustrasi yang sesuai untuk menstimulus HOTS peserta didik yaitu wacana, gambar, video, animasi, dan simulasi (termasuk grafik, fenomena dan eksperimental) yang mengaitkan fenomena-fenomena yang ada dalam kehidupan sehari-hari dapat memberikan rangsangan berpikir kepada peserta didik. Ada perbedaan rata-rata hasil tes peserta didik berdasarkan empat tipe soal (true or false, multiple choice, fill in the blank dan matching) yang mampu mengukur HOTS peserta didik. Aspek materi dan aspek konstruksi memiliki persentase tingkat pencapaian sebesar $60 \%<\mathrm{V} \leq 100 \%$ dengan kategori valid. Sedangkan untuk aspek bahasa dan aspek ilustrasi, tipe soal quiz and question setting memiliki persentase tingkat pencapaian sebesar $80 \%<\mathrm{V} \leq 100 \%$ dengan kategori sangat valid. Asesmen HOTS berbasis CBT hasil pengembangan praktis digunakan untuk mengukur HOTS peserta didik pada materi induksi elektromagnetik untuk mata pelajaran fisika di SMA.

\section{Daftar Pustaka}

Agustihana, S., \& Suparno, S. (2019). Development of HOTS oriented cognitive problems in thermodynamics for senior high schools. Jurnal Penelitian Fisika dan Aplikasinya (JPFA), 9(1), 44-54.

Anderson, L. W., \& Krathwohl, D. R. (2010). Kerangka landasan untuk pembelajaran, pengajaran, dan asesmen. Yogyakarta: Pustaka Pelajar, 300(300), 0.

Arikunto, S. (2012). Prosedur penelitian suatu pendekatan praktek. Rineka Cipta.

Borg, W. R. and Gall, M.D. (1989). Educational research: an introduction 5th. New York: Longman.

Brookhart, S. M. (2010). How to assess higher-order thinking skills in your classroom. ASCD.

Creswell, J. W. (2013). Steps in conducting a scholarly mixed methods study.

Erfan, M., \& Ratu, T. (2018). Pencapaian HOTS (higher order thinking skills) mahasiswa program studi pendidikan fisika FKIP Universitas Samawa. Jurnal Pendidikan Fisika Dan Teknologi, 4(2), 208-212.

Gunawan, G., \& Prabowo, D. A. (2017). Sistem ujian online seleksi penerimaan mahasiswa baru dengan pengacakan soal menggunakan linear congruent method (Studi kasus di Universitas Muhammadiyah Bengkulu). Jurnal Informatika Upgris, 3(2).

Himah, F., Sudarti, S., \& Subiki, S. (2017). Pengembangan instrumen tes computer based test-higher order thinking (CBT-HOT) pada mata pelajaran fisika di SMA. Jurnal Pembelajaran Fisika, 5(1), 89-95.

Ikhwan, M., Suyatna, A., \& Sesunan, F. (2015). Pengembangan kuis interaktif tipe fill in the blank untuk melatih kemampuan eksplorasi fenomena fisika. Jurnal Pembelajaran Fisika, 3(1).

Istiyono, E., \& Subroto, S. (2017). Pengembangan instrumen asesmen pengetahuan fisika berbasis komputer untuk meningkatkan kesiapan peserta didik dalam menghadapi ujian nasional berbasis komputer. Jurnal Pendidikan Matematika Dan Sains, 5(1), 123085.

Jancarík, A., \& Kostelecká, Y. (2015). The scoring of matching questions tests: a closer look. Electronic Journal of E-Learning, 13(4), 270-276.

King, F. J., Goodson, L., \& Rohani, F. (2010). Assessment \& evaluation educational services program: Higher-order thinking skills. Washington, DC: A Publication of the Educational Services Program.

Novrianti, N. (2014). Pengembangan computer based testing (CBT) sebagai alternatif teknik penilaian hasil belajar. Lentera Pendidikan: Jurnal Ilmu Tarbiyah dan Keguruan, 17(1), 34-42. 
Osterlind, S. J. (2002). Constructing test items: multiple-choice, constructed-response, performance, and other formats. Kluwer Academic Publishers.

Putri, B. A. Y., \& Raharjo. (2017). Empirical validity questions of high order thinking (HOT) evaluation instrument based on computer based test (CBT) at sensory system sub topic of student class XI senior high school. Berkala Ilmiah Pendidikan Biologi (BioEdu), 6(3), 353-359.

Schraw, G., \& Robinson, D. H. (2011). Assessment of higher order thinking skills. IAP.

Scully, D. (2017). Constructing multiple-choice items to measure higher-order thinking. Practical Assessment, Research, and Evaluation, 22(1), 4.

Soeharto, S., \& Rosmaiyadi, R. (2018). The analysis of students' higher order thinking skills (HOTS) in wave and optics using IRT with winstep software. Journal of Educational Science and Technology (EST), $1(1), 145-150$.

Sugiyono. (2015). Metode penelitian dan pengembangan research and development. Alfabeta.

Sugiyono. (2017). Metode penelitian dan pengembangan research and development. Alfabeta.

Suyatna, A., Viyanti, V., \& Rosidin, U. (2020). Optimizing computer-based hots instruments: an analysis of test items, stimulus, and quiz setting based on physics teachers' perceptions. Universal Journal of Educational Research, 8(3D), 97-105.

Syahputra, E., \& Surya, E. (2017). The development of learning model based on problem solving to construct high-order thinking skill on the learning mathematics of 11th grade in SMA/MA. Journal of Education and Practice, 8(6), 80-85.

Yen, T. S., \& Halili, S. H. (2015). Effective teaching of higher order thinking (HOT) in education. The Online Journal of Distance Education and E-Learning, 3(2), 41-47. 